\title{
Ventricular modification in carbachol-induced drinking: Reply to Routtenberg'
} KHALIL A. KHAVARI, University of Wis-
consin-Milwaukee, Milwaukee, Wis. 53201

Two recent studies (Myers \& Cicero, 1968; Khavari, Heebink, \& Traupmann, 1968) presented data which failed to support the view proposed by Routtenberg that carbachol-induced drinking may be due to ventricular modification (Routtenberg, 1967). Routtenberg (1968a, b) has raised some questions regarding the above two studies. In this note I am answering the three questions posed by Routtenberg (1968b) regarding our report (Khavari et al, 1968).

(1) "The purpose of this note is to point out that the negative results of Khavari et al (1968) may be in part attributed to the same problem of application of excessive amounts of carbachol [Routtenberg, 1968b,p. 99]." Routtenberg's previous comment (1968a) on Myers and Cicero's report is in point: "Thus, most prior investigations have administered a small quantity of carbachol $(0.5-5 \mu \mathrm{g})$ in a single application, and then tested for the effects of such administration immediately after the single application for about a 1-h period [p. 106]." In our study (Khavari et al, 1968) we tested five dosages which are considered small by Routtenberg himself. In addition, the water intake of the rats was measured for a 1-h period immediately after application of a single dose, in the best tradition of "most prior investigations." Clearly, the doses of carbachol used in our study were not excessive.

Routtenberg (1968b) has performed a Spearman rank correlation coefficient test with selected portions of our data (Khavari et al, 1968; Table 1; comparison of mean water intakes with the five doses of carbachol) and reported that there is a significant relation between dose level and water intake. However, the above statistical reasoning not only fails to support his point but ignores the remainder of our data. Specifically, when changes in water intake of each group under a given dose of

Mean water intake in $\mathrm{ml}$ for predrug and drug tests are shown in Columns 2 and 3, respectively. Column 4 shows the water intake of each group of Ss under a given dose of carbachol, expressed in per cents of their intake under predrug saline.

\begin{tabular}{|c|c|c|c|c|}
\hline $\begin{array}{l}\text { Carbachol Dose } \\
(\mu \mathrm{g} / \mathrm{rat})\end{array}$ & Predrug & Drug & $\begin{array}{l}\text { Intake under } \\
\text { Drug \% Predrug }\end{array}$ & Rank \\
\hline $\begin{array}{l}0.25 \\
0.5 \\
1.0 \\
2.0 \\
4.0\end{array}$ & $\begin{array}{l}24.2 \\
24.8 \\
23.4 \\
24.4 \\
21.8\end{array}$ & $\begin{array}{l}27.2 \\
22.7 \\
22.6 \\
20.8 \\
19.5\end{array}$ & $\begin{array}{r}112 \\
91 \\
96 \\
85 \\
89\end{array}$ & $\begin{array}{l}1 \\
3 \\
2 \\
5 \\
4\end{array}$ \\
\hline
\end{tabular}
doses did not." I cannot find any statemen by Fisher and Levitt to the effect that they have obtained drinking with low intraventricular doses of carbachol. However, in the same paper that Routtenberg has cited, Fisher and Levitt state that "Direct ventricular injection of the amount of crystalline carbachol we usually insert into brain (1 to $3 \mu \mathrm{g}$ ) produced catatonia, tremors, or bizarre motor behavior. Significant amounts of drinking did not occur [Fisher \& Levitt, 1967,p. 840]."

(2) Routtenberg's second point deals with the fact that we have used water-deprived Ss. He states that "... the authors report the effect of carbachol on $23 \mathrm{~h}$ water deprived animals. Such a procedure would raise baseline or control levels, and could mask any effects of carbachol-induced drinking that were present [Routtenberg, 1968b, p. 99]." It is difficult to appreciate the above point for two reasons. First, in our study (Khavari et al, 1968) measures of drinking for determination of baseline control and carbachol conditions were taken when the Ss were exposed to the same identical water deprivation schedule, i.e., both predrug and drug tests were performed when the Ss were water-deprived for exactly $23 \mathrm{~h}$. Second, the fact that carbachol application in the central thirst circuit of water-deprived rats significantly increases their drinking over the nonstimulated controls is well documented (e.g., see Miller 1965; Grossman, 1967).

(3) Routtenberg's third comment is in regard to the vehicle employed in our study ( $10 \mu \mathrm{l}$ of distilled water). He suggested that "Such a hypotonic solution when injected into the ventricle might act to suppress drinking behavior [Routtenberg, 1968b, p. 99]." This possibility can be also excluded on the ground that $10 \mu \mathrm{l}$ of a hypotonic solution can hardly significantly alter the tonicity of the rats' cerebrospinal fluid. The brain ventricles of rats contain anywhere from $120-500 \mu \mathrm{l}$ of fluid (see Cicero \& Myers, 1968; Reed et al, 1967); therefore, our $10 \mu \mathrm{l}$ of hypotonic solution seems to be an unlikely source of confoundment.

At this time, on the basis of data from our laboratory and the findings of Myers and his colleagues at Purdue, we are impelled to conclude that the notion of ventricular modification fails to account for carbacholinduced drinking.

\section{REFERENCES}

CICERO, T. J., \& MYERS, R. D. Clarification of the role of the cerebral ventricles in cholinergically induced drinking. Psychonomic Science, $1968,12,343$

FISHER, A. E., \& LEVITT, R. A. Drinking induced by carbachol: Thirst circuit or ventricular modification? Science, 1967, 157, 839-841.

GROSSMAN, S. P. A textbook of physiological psychology. New York: John Wiley \& Sons, 1967.

KHAVARI, K. A., HEEBINK, P., \& TRAUPMANN; J. Effects of intraventricular carbachol and eserine on drinking. Psy chonomic Science, 1968, 11, 93-94.

MILLER, N. E. Chemical coding of behavior in the brain. Science, 1965, 148, 328-338.

MYERS, R. D., \& CICERO, T. J. Are the cerebra ventricles involved in thirst produced by a cholinergic substance? Psychonomic Science, $1968,10,93-94$

REED, D. J., WITHROW, C. D., \& WOODBURY D. M. Electrolyte and acid-base parameters of rat cerebrospinal fluid. Experimental Brain Research, 1967, 3, 212-219.

ROUTTENBERG, A. Drinking induced by carbachol: Thirst circuit or ventricular modification? Science, $1967,157,838-839$.

ROUTTENBERG, A. Dose-response problem in testing the ventricular hypothesis: Reply to Myers and Cicero. Psychonomic Science, 1968a, $11,106$.

ROUTTENBERG, A. Dose-response problem in testing the ventricular hypothesis: II. Reply to Khavari, Heebink, and Traupmann. Psychonomic Science, 1968 b, 12, 99. NOTE

1. Due to a family illness I have been abroad for the past few months and returned recentiy to the U.S. Therefore, my apologies for the delay in preparation and submission of this overdue note. 